\title{
Simultaneous thermodynamic and dynamical characterisation using in situ calorimetry with neutron spectroscopy
}

\author{
D. Fornalski ${ }^{1}$, V. García Sakai ${ }^{1}$, S. Postorino ${ }^{2}$, I. Silverwood ${ }^{1}$, C. Goodway ${ }^{1}$, \\ J. Bones $^{1}$, O. Kirichek ${ }^{1}$, and F. Fernandez-Alonso ${ }^{1}$ \\ ${ }^{1}$ ISIS, STFC, Rutherford Appleton Laboratory, Didcot, OX11 0QX, UK \\ E-mail: damian.fornalski@stfc.ac.uk \\ ${ }^{2}$ University of Rome, Tor Vergata, Italy
}

Received October 24, 2018

\begin{abstract}
Both Differential Scanning Calorimetry (DSC) and Quasi-elastic Neutron Scattering (QENS) are powerful analytical tools actively used in studies of phase transitions in complex solid and liquid systems. DSC is typically used to map phase transition temperatures and identify sample states, and QENS provides information on the molecular scale dynamical motions, such as molecular self-diffusion or glassy dynamics, associated with such transitions. Both techniques provide highly valuable complementary information about the sample and in many cases it would be advantageous to measure in parallel with a view to linking the two observables. The biggest challenge is that the cell design which differs greatly between the two methods. Here we present a first attempt at designing a cryogenic system which will allow the simultaneous measurement of calorimetric transitions and QENS measurements, as tested on the neutron spectrometer IRIS at ISIS neutron scattering facility. The system temperature range is from $10 \mathrm{~K}$ to $300 \mathrm{~K}$. We present and discuss the initial design of the system, preliminary test results, current challenges and limitations, and future directions.
\end{abstract}

Keywords: neutron spectroscopy, calorimetry, simultaneous thermodynamic and dynamical characterisation, quasi-elastic neutron scattering.

\section{Introduction}

In recent years the popularity of analytical tools in the area of cryocrystal research has been rapidly growing. In situ and in operando techniques with neutron measurements are also becoming more popular. Two of the methods, Differential Scanning Calorimetry (DSC) and Quasielastic Neutron Scattering (QENS) [1] have attracted particular interest because of high sensitivities and relatively short time required by complete measurements. In addition, these two methods are fundamentally complimentary because DSC is typically used to map phase transition temperatures and identify sample states, and QENS provides information on the nanoscopic scale dynamical motions, such as molecular self-diffusion [2] or glassy dynamics, associated with such transitions.

The first system where DSC was combined with neutron measurements was in the area of Small Angle Neutron Scattering (SANS), which measures structures in materials in the range of 1-100 $\mathrm{nm}$ [3]. In this case the small sample size and the simple transmission geometry and sample ar- rangement in the neutron beam, significantly simplifies the design of an in situ calorimeter.

In this paper, we present results of the first in situ calorimeter which will allow the simultaneous measurement of calorimetric transitions and QENS. The design is completely different to that used with SANS and much more challenging to conceive. The system has been tested on the neutron spectrometer IRIS at ISIS neutron scattering facility [4]. The operating temperature range is $10 \mathrm{~K}$ to $300 \mathrm{~K}$, as it is to be used with the standard IRIS cryogenic system. We present and discuss an initial design of the system, preliminary test results, current challenges and limitations, and directions for its further development. Between the different existing calorimetry methods, DSC has been chosen as method for the design, as it is the most commonly used laboratory tool used in the areas of science of relevance.

Various challenges were faced considering simultaneous measurements with QENS. Firstly, commercially available DSC equipment typically requires very small sample sizes, milligrams including the sample container, due to a need of 
achieving accurate and homogeneous temperature distribution across the sample. Sample sizes required for neutron spectroscopy are at least two orders of magnitude bigger, due to typical neutron beam sizes being of the order of centimeters and the sample container design having to withstand typical geometrical and sample environment constraints, resulting in total sample masses of the order of tens of grams. Secondly, in order to achieve temperatures in the range of $10-300 \mathrm{~K}$, which is typical for QENS measurements, the common method is to use a closed-cycle refrigerator based on compressed helium. This requires evacuation of He gas environment around the sample. Thirdly, sample geometry is also different, with QENS spectroscopy detectors typically covering $\sim 20-160$ degree and thus favouring a cylindrical geometry. Fourthly, of crucial importance for QENS measurements is the need for an annular geometry where the annular gap is typically small (from $0.1 \mathrm{~mm}$ to $1 \mathrm{~mm}$ ) to avoid multiple scattering events. Finally, the sample container material is the same, typically aluminium, as it offers very good thermal conductivity and is almost transparent to the neutrons. In addition, the neutron scattering measurement requires minimal extra material around the sample to avoid contaminating scattering signals. To our knowledge, there is no other known sample cell design that allows the combination of QENS and DSC. In this paper we describe an initial cell design and show preliminary thermodynamic results, which point towards a working prototype.

\section{Design}

The type of experimental samples imposes limitations on the choice of cell design. A number of considered potential samples are volatile liquids. This, combined with the requirement of vacuum environment imposes a need for vacuum tight container, as the calorimeter is expected to work with standard equipment, namely $100 \mathrm{~mm}$ center stick and top loading cryocooler (CCR) [5]. For a good and accurate calorimeter, there is a need to provide a homogenous temperature environment for both sample cell and reference cell. The presence of ionising radiation limits the choice of materials in the proximity of neutron beam. However, even more importantly, transmission of the neutrons is critical for an optimal design, so that the scattering signal arising from the cell material does not dominate the observable neutron signal. Instead, it should be the sample signal which dominates the scattering signal. Therefore both sample and reference cell material has to be chosen to be "neutron friendly". In addition, a critical parameter for the chosen calorimetry method is that the mass ratio between the sample and the sample cell is kept as small as possible, to resolve the calorimetric signal.

The calorimeter design consists of a sample and a reference cell (Fig. 1) that are connected through good conductance thermal link to the CCR. Helium exchange gas is used within the CCR chamber to provide additional thermal sup-

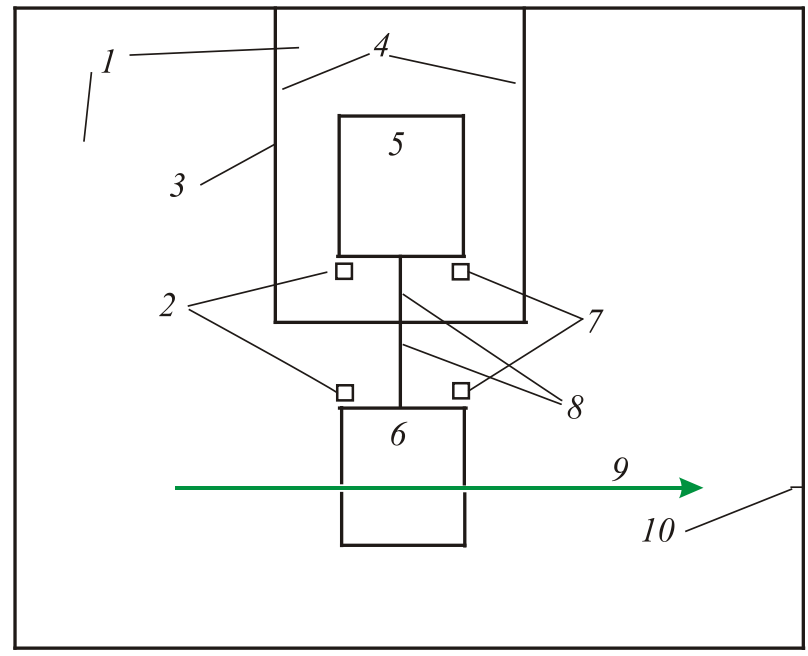

Fig. 1. Conceptual sketch of an in situ calorimeter for QENS measurements: vacuum/exchange gas (1); temperature sensors (2); thermal anchor (3); thermal links (4); empty/reference cell (5); annular cell with sample $(6)$; individual heaters $(7)$; weak thermal links (8); neutron beam line (9); CCR (10).

port via convection. The sample and reference cells are connected to homogenous temperature thermal link with CCR via weak thermal links. The design of the cells is partially derived as a result of manufacturing challenges in traditional machining/welding processes imposed by cell's design requirements. A 3D printing Selective Laser Sintering (SLS) method has been chosen as method for creating the cell.

The sample and reference cells have been designed to have annular shape (Fig. 2) with $0.5 \mathrm{~mm}$ sample gap and $0.5 \mathrm{~mm}$ cell wall thickness (currently limit for manufacturing method used), to be used only for liquids. The sample is filled through the top and fills the $0.5 \mathrm{~mm}$ gap (shown in black in Fig. 2). The cells are terminated from both ends with hollow conical shapes for ease of sample loading/unloading and cell cleaning. This allows for substantial reduction of the size of the sealing flanges in comparison to the cells used for standard QENS measurements on IRIS. The cell manufactured as per above drawing reduces the critical parameter of cell to sample volume ratio (translated to thermal mass) to an approximate value of 3, whereas for standard QENS cells it is closer to 10 .

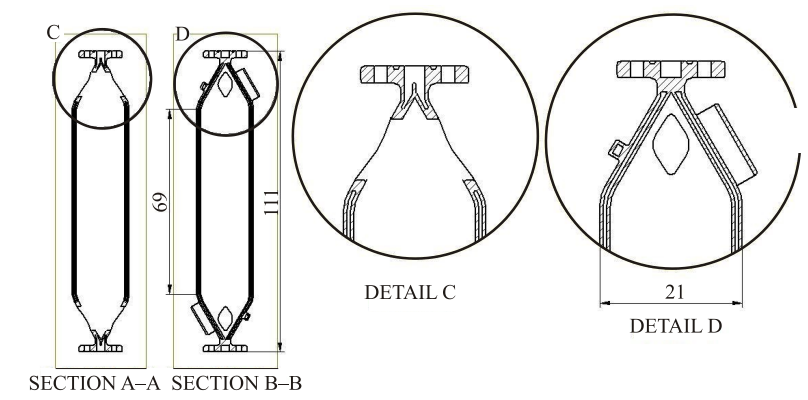

Fig. 2. Design of 3D printed in situ DSC/QENS cell. 


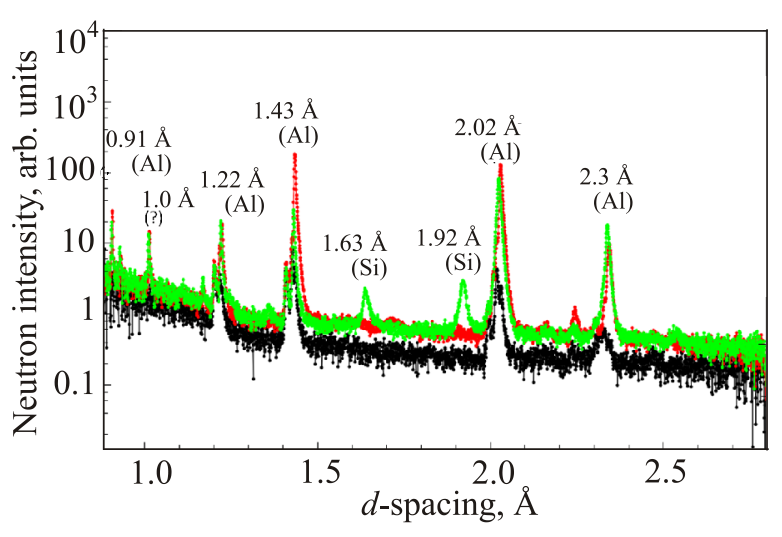

Fig. 3. (Color online) Diffraction patterns of 3D-printed sample cell. Black shows the empty CCR, red is the standard IRIS annular cell, and green shows the 3D-printed cell.

As previously mentioned, the material used for the cells needs to be neutronically compatible (e.g., in terms of its "transparency"). The cell has been made of laser sintered AlSi10Mg a commercially available material. The diffraction pattern (Fig. 3) was measured on IRIS and compared with the standard annular IRIS cell made of an aluminium alloy. The resulting patterns are shown in Fig. 3 and show that the signals are very similar, except that the calorimeter cells have some Bragg peaks arising from the $\mathrm{Si}$ in the cell material. The contribution to the signal from this is small and thus the chosen material is deemed good for the set-up.

Most of all the remaining parts of the in situ DSC assembly are machined of aluminium alloy, except of PTFE baffle rings (see Fig. 4). Weak thermal links between sample/reference cells and thermal anchor are machined of G10 resin for small thermal conductivity reasons. The DSC calorimeter assembly is attached to a standard $100 \mathrm{~mm}$ centre stick (as shown in Fig. 4). Heaters are mounted on the sur-
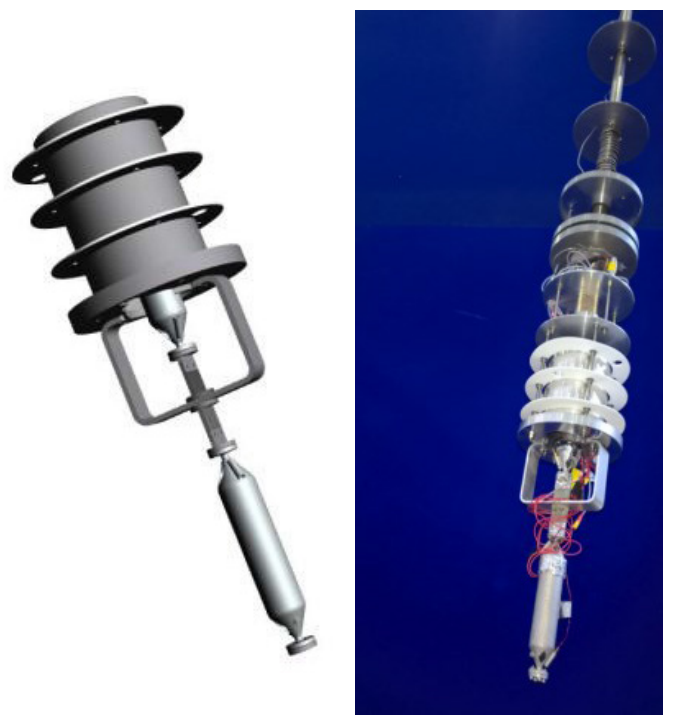

Fig. 4. DSC assembly 3D image (left) and real system mounted on the CCR stick (right). face and sensors are inserted to 3D printed pockets on conical part of the cans. Top and bottom parts of the cells have capability of being heated and temperature monitored.

\section{Preliminary results}

Initial tests were performed using two common glassforming liquids, glycerol and toluene. Once the system is cooled and thermally equilibrated in the CCR, a measurement is done by heating both sample and reference cells independently with a set value of the ramp rate, which is the same for both, in degrees per minute. The difference in heat output between sample and reference cells is directly proportional to the enthalpy change of the sample including any phase change. An important part for achieving a good control of the system is minimizing the temperature difference between sample and reference cells, achievable with the two heater design. Figure 5 shows recorded temperature differences between extreme ends of the setup, namely between sample cell's bottom sensor and reference cell's top sensor. Both graphs are for $1 \mathrm{~K} / \mathrm{min}$ temperature ramp rate. The graph Fig. 5(a) is for glycerol and Fig. 5(b) is for toluene. Just from recording the changes in temperature, transitions in the liquids are already visible, one for
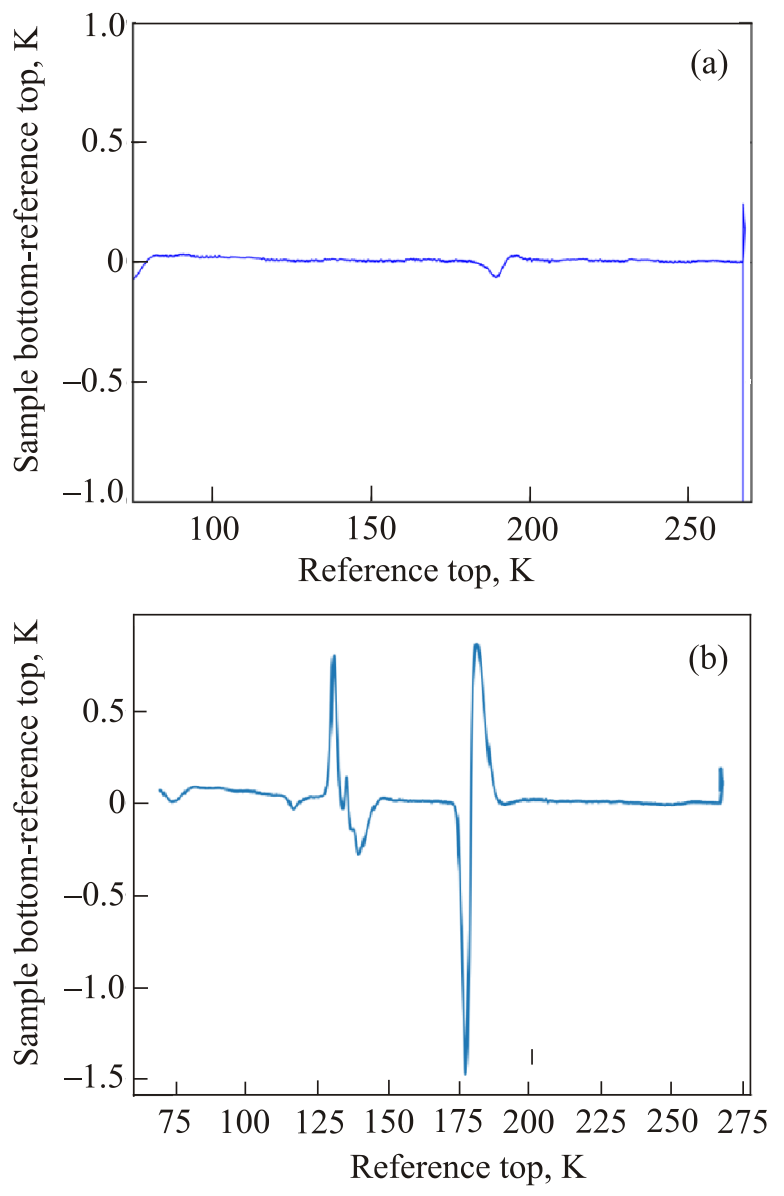

Fig. 5. Temperature difference between sample cell's bottom sensor and reference cell's top sensor for glycerol (a), and toluene (b). Temperature ramp rate is $1 \mathrm{~K} / \mathrm{min}$. 

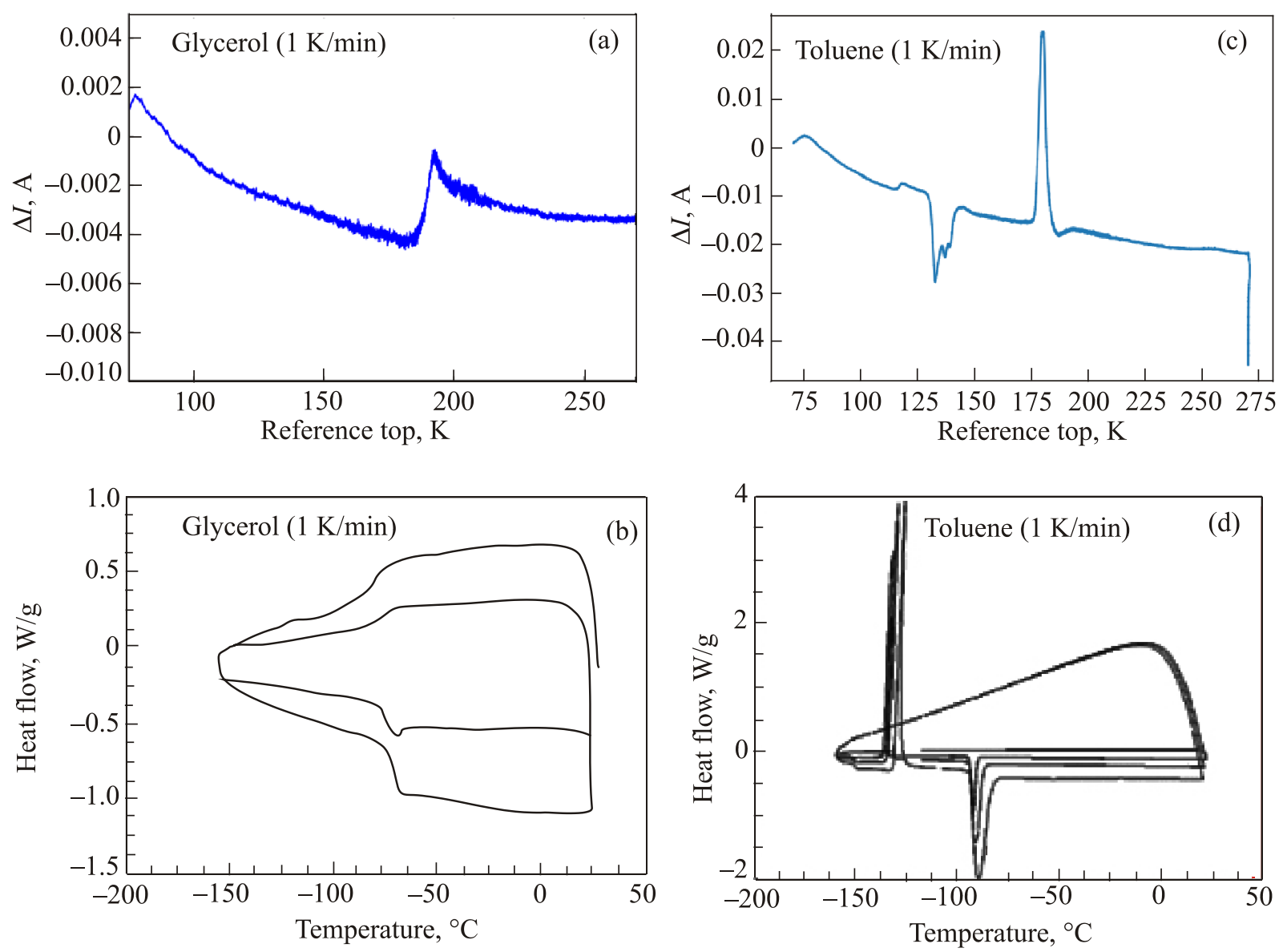

Fig. 6. Preliminary glass transition results (a), (c) in comparison with TA2000 Instruments DSC Industry standard test results (b), (d). Current subtraction $\Delta I=I_{\text {sample }}-I_{\text {ref }}$, A.

glycerol at around $190 \mathrm{~K}[6]$ and three for toluene $117 \mathrm{~K}$ [7], $148 \mathrm{~K}$ [8], $178 \mathrm{~K}$ [8]. All agree nicely with what is expected for these liquids. A much more accurate reading for the DSC signal is through the measurement of changes in the heater output (as a current). This is shown in Fig. 6 for the same liquids; the transitions are visible as before. This set-up is able to pick-up the smaller glass transitions in addition to larger crystallization and melting first order transition. For comparison, DSC signals from an industry standard TA2000 Instruments DSC are shown in Fig. 6, where the glass transition for glycerol $190 \mathrm{~K}$ [6] and toluene $117 \mathrm{~K}$ [8] are clearly seen.

\section{Discussion}

The developed sample cell has its limitations regarding what types of samples can be used and in what regimes.

Firstly, due to small opening for sample loading (essential for sealing and reduced weight) in the developed cell, only liquid samples are feasible and highly viscous liquids are restricted (although loading with evacuated cell works with glycerol - relatively viscous liquid). An alternative solution would have to be developed for powder samples.
Secondly, the current sample cell design allows for measurements in temperature range $10-300 \mathrm{~K}$. Due to the manufacturing method, the cell cannot be pressure rated (pressure system regulations do not allow yet for 3D printed equipment being used as pressure vessels), therefore heating the sample can only be considered for a temperature range not approaching the boiling point of the sample. Moreover, the sealing method for the sample cell is based on indium wire, therefore temperature limit for that is set to be $373 \mathrm{~K}$. Modifications (machining of sealing surface) to the sample cell would be required for implementing an alternative sealing method.

Thirdly, QENS is typically used to measure the dynamics of hydrogenated materials which commonly require a sample thickness of $0.1 \mathrm{~mm}$. The design does not currently allow this, but is ideally suited for deuterated materials or for hydrogenated components in deuterated solution. One good example is for use with amphiphilic molecule selfassemblies in $\mathrm{D}_{2} \mathrm{O}$ (e.g., surfactant micelles or model lipid membranes).

Lastly, the sample geometry, thickness, materials, may vary due to scientific requirements; therefore new cell design may be required. 
There are also limitations with the system developed with regards of control. Initial QENS+DSC measurements show a loss in DSC sensitivity owing to the measurement methods used for QENS. While the data shown for the DSC proof of concept is based on a continuous temperature ramp and the measurement of the current every few seconds, the standard neutron ramp is based on a 'step and wait/count' ramp where the wait/count step is of the order of 10-15 mins to achieve enough statistical accuracy. Furthermore, standardised calibration scans of the equipment may be required for more accurate results. Also, control algorithm/software development is required for convenient use of the equipment as part of the routine neutron user service.

\section{Conclusions}

The DSC system developed in its current design allows thermodynamic measurements and is compatible with neutronic measurements (sample size and cell material). Further developments are required to couple the system with QENS measurements and extend to a range of sample types, as currently it is only suitable for non-viscous liquids.

\section{Acknowledgements}

We would like to thank ISIS colleagues for support and contribution to the project.

1. M. Bée, Quasi-elastic Neutron Scattering Principles and Application in Solid State Chemistry, Biology and Materials Science, Adam Hilger (1988).

2. Dynamics of Soft Matter: Neutron Applications, Victoria Garcia Sakai, Christiane Alba-Simionesco, and Sow Hsin Chen (eds.), New York (2012).

3. S.A. Pullen, N. Booth, S.R. Olsen, B. Day, F. Franceschini, D. Mannicke, and E.P. Gilbert, Sci. Technol. 25, 055606 (2014).

4. C.J. Carlile and M.A. Adams, Physica B 182, 431 (1992).

5. Beth Evans, Richard Down, Jeff Keeping, Oleg Kirichek, and Zoe Bowden, Sci. Technol. 19, 034018 (2008).

6. W. Zheng and S.L. Simon, J. Chem. Phys. 127, 194501 (2007).

7. O. Yamamuro, I. Tsukushi, A. Lindqvist, S. Takahara, M. Ishikawa, and T. Matsuo, J. Phys. Chem. B 102, 1605 (1998).

8. Deepanjan Bhattacharya and Vlad Sadtchenko, J. Chem. Phys. 141, 094502 (2014).
Одночасна термодинамічна та динамічна характеризація методами in situ калориметрії та нейтронної спектроскопії

D. Fornalski, V. García Sakai, S. Postorino, I. Silverwood, C. Goodway, J. Bones, O. Kirichek, F. Fernandez-Alonso

Диференційна скануюча калориметрія (DSC) та квазіпружне розсіяння нейтронів (QENS) - потужні аналітичні інструменти, які активно використовуються при вивченні фазових переходів у складних твердих і рідких системах. DSC зазвичай використовується для знаходження температур фазового переходу та ідентифікації станів зразка, а QENS надає інформацію про пов'язану з фазовими переходами динаміку явищ молекулярного масштабу таких, як молекулярна самодифузія або склування. Обидва методи надають можливість отримання дуже цінної взаємодоповнюючої інформації про зразок, і в багатьох випадках доцільно паралельно виконувати вимірювання 3 метою об'єднання двох спостережень загальним трактуванням. Суттєвою проблемою є вибір конструкції комірки, вимоги до якої для цих двох методів різні. $\mathrm{У}$ цій роботі ми представляємо першу спробу створення кріогенної системи, що дозволяє одночасно проводити калориметричні вимірювання та вимірювання QENS, а потім зіставляти результати обох спостережень. Дослідження виконано на нейтронному спектрометрі IRIS та установці розсіювання нейтронів ISIS, робочий діапазон температур системи складає від 10 до 300 К. У роботі наведено та обговорено вихідну конструкцію системи, попередні результати випробувань, поточні проблеми та недоліки, а також перспективи застосування.

Ключові слова: нейтронна спектроскопія, калориметрія, одночасна термодинамічна та динамічна характеризація.

\section{Одновременная термодинамическая и динамическая характеризация методами in situ калориметрии и нейтронной спектроскопии \\ D. Fornalski, V. García Sakai, S. Postorino, I. Silverwood, C. Goodway, J. Bones, O. Kirichek, F. Fernandez-Alonso}

Дифференциальная сканирующая калориметрия (DSC) и квазиупругое рассеяние нейтронов (QENS) являются мощными аналитическими инструментами, активно используемыми при изучении фазовых переходов в сложных твердых и жидких системах. DSC обычно используется для нахождения температур фазового перехода и идентификации состояний образца, a QENS предоставляет информацию о связанной с фазовыми переходами динамике явлений молекулярного масштаба таких, как молекулярная самодиффузия или стеклование. Оба метода дают возможность получения очень ценной взаимодополняющей информации об образце, и во 
многих случаях целесообразно параллельно выполнять измерения с целью объединения двух наблюдений общей трактовкой. Существенной проблемой является выбор конструкции ячейки, требования к которой для этих двух методов различны. В этой работе мы представляем первую попытку создания криогенной системы, позволяющей одновременно проводить калориметрические измерения и измерения QENS, а затем сопоставлять результаты обоих наблюдений. Исследования выполнены на нейтронном спектрометре IRIS и установке рассеяния нейтронов ISIS, рабочий диапазон темпе- ратур системы составляет от 10 до 300 К. В работе представлены и обсуждены исходная конструкция системы, предварительные результаты испытаний, текущие проблемы и недостатки, а также перспективы применения.

Ключевые слова: нейтронная спектроскопия, калориметрия, одновременная термодинамическая и динамическая характеризация. 